\title{
調理によるニコチン酸の溶出に関する研究
}

\section{Studies on the Niacin Loss in Cooking}

(昭和 31 年 6 月 1 日受理)

\section{宮 本 悌 次 郎}

(Teijiro Miyamoto)

緒

言

ニュチン酸 (以下 NA と略す) は一般に他のビタミ ンに比して熱， $\mathrm{pH}$, 酸化㓮等に対して安定であるが，水 に易溶である為，かなり洶洗，蒸募等調理操作に上り廃 萧されるすのと考えられる。しかしえ等に関する研究は 特に我国に於て少い。そこで著者等は淘洗を行 5 米麦 類, 主として煮たりゆでたりする操作をする個々の肉類, 野菜類並に普通の副食献立について生鮮品々調理後の NA の差を求めるとともに之等の值と食品分析表から計 算によつて求めた NA 量との割合を求めた。一方我国 の主要な NA 源となつている䉯節煮出汁中の NA 量 についても検討したので之等の結果を報告する。

\section{実験方法並に結果}

\section{1. ニコチン酸の定是方法}

著者の化学的定量法”による。

\section{2. 主食について}

試料として配給内地米，及びえに押麦，外米を加えた すのをとり，之を一般の家庭で行われている樣に上澄液 がきれいになる迄よく手で硞い，普通のアルミニューム
守田久子

(Hisako Morita)
伊丹磨智子

(Machiko Itami)

の鉒で吹きこぼすことのない㨾に炊いてからそのNAを 定量し，対照して同一試料の汻洗前の NA 量を測定し て比較した。又炊飯後の NA 实测值を佂品分析表”) 上 り求めた計算值と比較した、等の結果を第 1 表に示す が NA は炊飯により 2/3〜1/2 が失われることを明ら かにした。

\section{3. 肉賎並に芧莱類について}

調理条件としては試料を $5 \sim 30 \mathrm{~g}$ とり, 水道水又は沸 滕水を $30 \sim 50 \mathrm{ml}$ 加えて試料が度浸万樣にし, 葉菜 類は 5 分, 根菜類, 肉類は 10 分煮沸した。試料の大き さも日常家庭で行う場合と同樣にしたが,この程度でよ く煮えた。かくして得たものを吸引舅過して㴓液と固型 物に分け，その各々の NA を定量して煮汁への移行率 を求め，又之等の和と生鮮時の NA 量から調理による 残存率を求めた結果を第 2 表に示寸。この表からこの程 度の調理では NA の破壊は殆どなく，いも類を除く他 の食品に於ては約半量の NA が省汁へ移行することが わかる。牛肉中の NA の移行率はやや高く, 鯨肉の方 は幾分低い。いも類の NA の煮汁への移行率の低いの はいも類か完全に煮える迄に水分か減少した為によるも のと考えられそ

第 1 表 主食中ニコチン酸の調理による損失

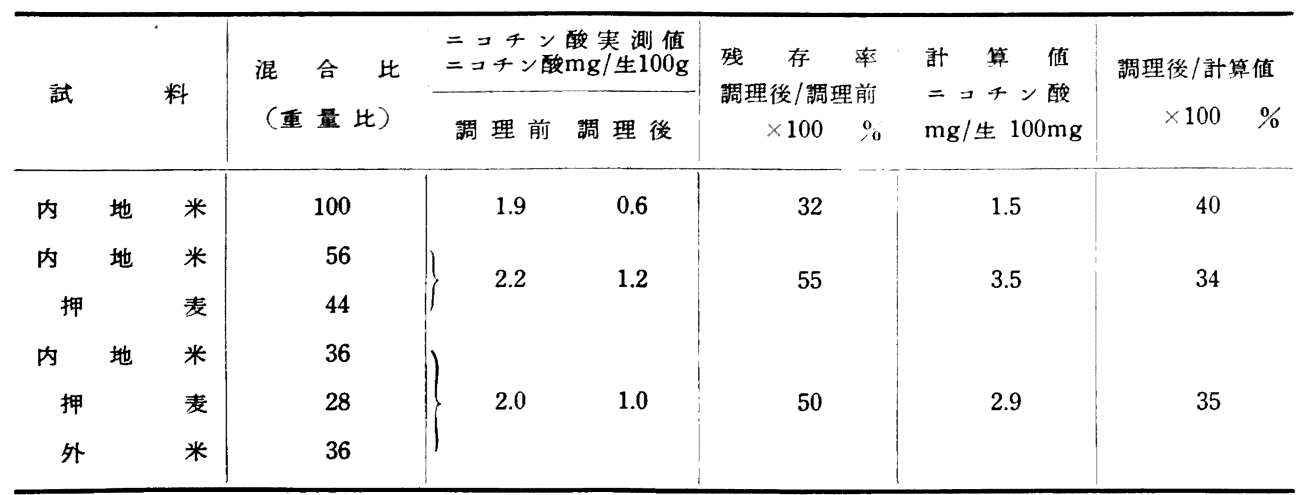


第 2 表 調理による副食類中ニコチン酸题の変化

\begin{tabular}{|c|c|c|c|c|c|c|}
\hline 食 & 品 名 & & $\begin{aligned} \text { 生鮮時二コ } \\
\text { チン酸含量 } \\
\text { mg\% }\end{aligned}$ & 点汁 & $\begin{array}{r}\text { ーの䔟 } \\
\%\end{array}$ & $\begin{array}{l}\text { 調理後の残 } \\
\text { 存率 }\end{array}$ \\
\hline 牛 & & 肉 & 3.6 & & 74 & 111 \\
\hline 豚 & r & 肉 & 2.6 & & 63 & 97 \\
\hline 鲸 & & 内 & 4.8 & & 35 & 100 \\
\hline d & r & ば & 4.3 & & 62 & 109 \\
\hline ב & L & 去 & 3.6 & & 60 & 96 \\
\hline מ & 机 & $w$ & 1.4 & & 52 & 98 \\
\hline あ & & ビ & 2.1 & & 61 & 108 \\
\hline & क & L & 9.4 & & 51 & 107 \\
\hline$w$ & & D. & 3.9 & & 44 & 98 \\
\hline 馬 & 鈴 & 薯 & 0.8 & & 16 & 86 \\
\hline 里 & & 苸 & 0.8 & & 13 & 100 \\
\hline ⿷ & $5 九 ん$ & & 0.9 & & 50 & 108 \\
\hline 白 & & 荣 & 0.6 & & 50 & 100 \\
\hline$\neq$ & $+\approx$ & ッ & 0.3 & & 50 & 93 \\
\hline 12 & & ぎ & 0.7 & & 50 & 114 \\
\hline 人 & & 参 & 0.4 & & 49 & 100 \\
\hline 大 & & 根 & 0.2 & & 50 & 100 \\
\hline れ & $h=$ & & 2.4 & & 52 & 96 \\
\hline ま & $つ た ~$ & V & 3.1 & & 53 & 110 \\
\hline z & $5 め$ & L & 1.1 & & 58 & 108 \\
\hline
\end{tabular}

次に主こ:かか、調理をするものについて試料の量を多 く奏際家庭で行う程度にとり，充分柔かくなる焃に食品
毎にその調理条件を变えて悠汁への移行率, 寸なわち摄 取されずに廃萧される割合を湘定した結果は第 3 表に示 寸如くでやはりいも類に於て移行率は低く，その他は 30 〜60\%の NA が煮汁中に移行している。

\section{4. 副食献立について}

本学女子学生の家庭に於ける1 日の献立 (副食) 並に 调理法を詳細にききとり, 之を研究室で忠実に再現し, その濐理前後の NA を定量した。次に我々がたで保 健食献立 2 例"3)についてもその調理前後の NA を定量 した そしてそ等の献立について食品分析表からその NA 量を㖕算によつて求めた。之等の値を調理前の NA 量に対寸る調理後の値の割台，すなわち調理による NA の残存率と計算值に対する調理後の NA 実測值の割合 とともに第 4 表に示す。この表から副食の普通の調理に よる NA 摃失は約 $10 \%$ 以下で主食の NA 損失率 45 一 68\%に比して著しく少い。

\section{5. 節薏出汁について}

市即の中級花かつおを試料とし，最も普通のたし方と して水に対して 2 8\% の鰹節をとり，種々の条件で加 熱し，沸瞵後1分たつて火からおろし，3 分間静置して

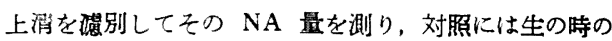

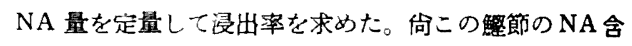
量は $42 \mathrm{mg}$ 。てであつた。この結果を第 5 表に示すか $2 \%$ 薢節を用い，沸滕水に直接入れてだすのが浸出率の点の

第 3 表 主にゆがく食品についてのゆで汁一のニコチン酸の移行率

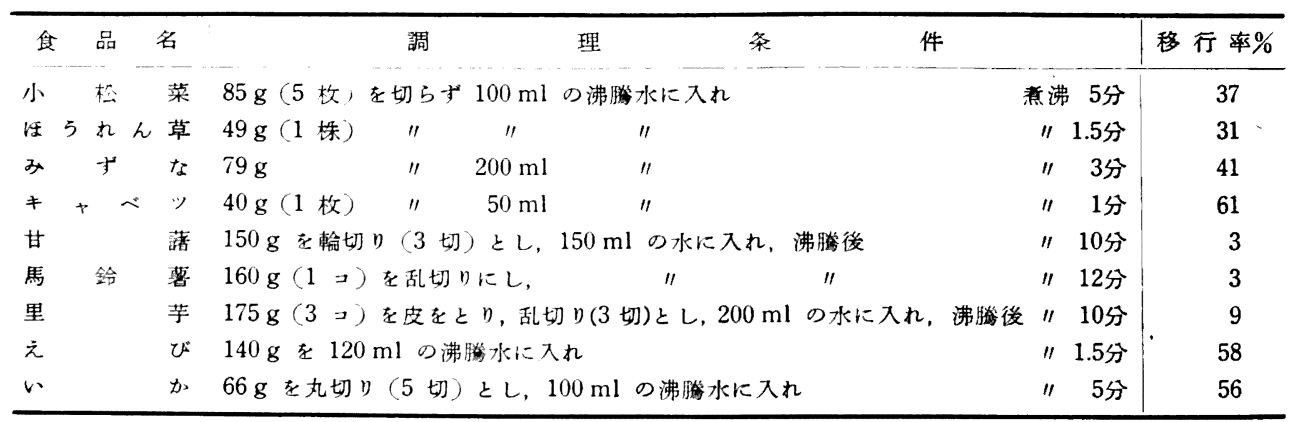

第 4 表 副食献立のニコチン酸の損失と計算值との比皎

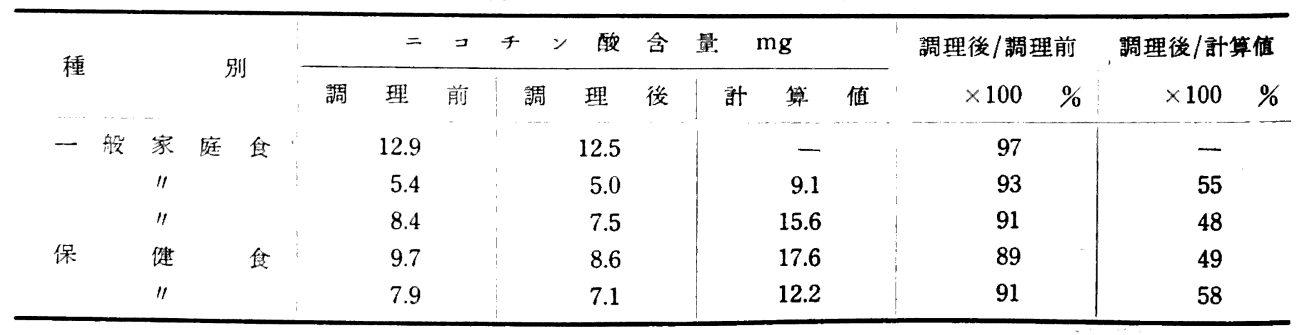

(144) 
第 9 巻 第 3 号

第 5 表等節の漫出法の差によるニコチン酸の浩出率

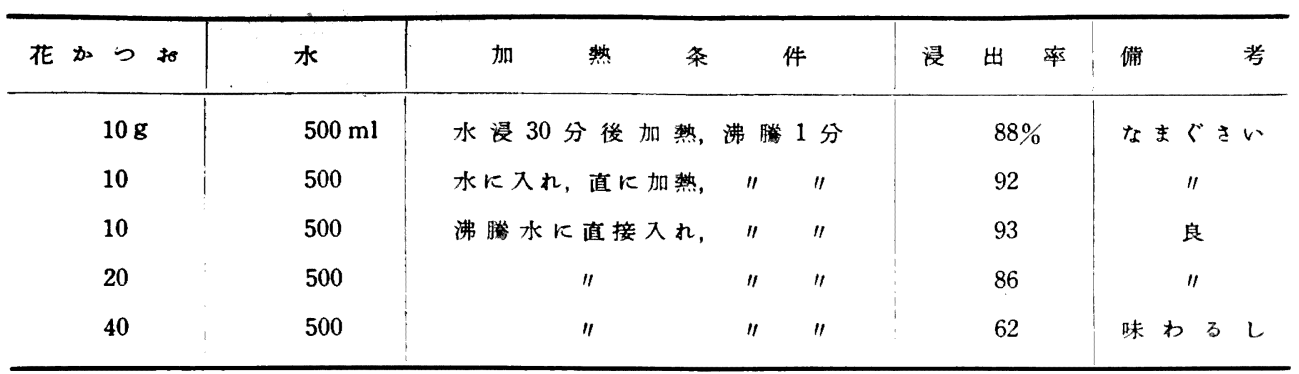

但し花かつたのニコチン酸含量は $42 \mathrm{mg} \%$ であつた。

みならず, 味, 香気の点からも最すよかつた，又味，香 気の点については吉松の結果”とも一致している，

\section{考察}

米麦の饮的による NA の損失が非常にこ大でするが之 は有本, 稆垣 ${ }^{5}$ す白米についてのべている樣に加䓡時よ りるその前の沟洗に於て失われるすのか殆どであると思 われる。從つて滛妷の玨度を少くす机ば損失が少くなる のは当然考えられることである：对計算值に対する割合 が麦飯に於て米飯のそれよりもむしろ低いのは我々の使 用した押麦が分析表の值より低かつた為と思われる，

肉類並に野菜類の NA の煮汁中への移行は著者の一 人がかつ做生物法で行つた結果6”とほほ似ている。又 調理条件を多少かえても結果に大差は認めないか，一定 の献立の場合には NA 全量の損失が少いのはゆかく操 作が少く，又否计等も共に用いられる場合が多い為であ る。調理後の NA 実測值の計算值汇対する割合が低い 理由として種々考えられるか，定量操作に関しては少く

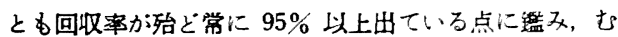
しろ使用材中の NA 量が分析表のそれと異る為によ るすのであろう。

\section{総括}

種々の食品を調理することにより失われるニコチン酸
量を測定して次の結果を得た

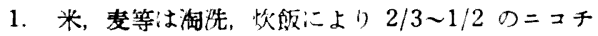
ン酸が失われる。

2. 副食についてはゆかく操作によつていも類を除く 他の食品に於て約半量のニコチン酸がゆで汁中に移行し たがいも類のそれの移行率は3〜16\%であつた。

3. 副食の献立については全調理操作により失われる ニコチン酸は $10 \%$ 以下であつた。

4. 鰹節煮出汁については最良の条件すなわら水に対 して $2 \%$ 。 鰁節を用い， 1 分劣沸で $90 \%$ 以上のニコチン 酸が漫出された

終りに御指導, 御校閲を睗わつた村田教授に深謝しま す。

向本研究の一部は第 9 回栄蓝食䊓学会総会に於て報告 した。

\section{文献}

1 ) 宮本: 阪市大家政紀要, 2, 164 (1954).

2）资源協会編：日本食品標浅成分表 (1954).

3) 守田：食生活, 50 (2), 114 (1956).

4) 吉松: 家政学雑誌, 5, 359 (1954).

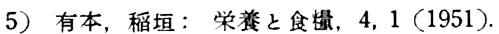

6）宮本，莉原：阪市大家政紀要，1，8 (1953).

(大阪市立大学家政学部) 